\title{
PENGGUNAAN EARNED VALUE ANALYSIS DI DALAM MENGUKUR KINERJA IT PROJECT
}

\author{
Yuliana Lisanti \\ Jurusan Sistem Informasi, Fakultas Ilmu Komputer, Bina Nusantara University \\ Jln. K.H. Syahdan No 9, Palmerah, Jakarta Barat 11480 \\ Lisanti@binus.edu
}

\begin{abstract}
IT Project's succesfulness can be measured from some factors such as project's time completion, project's cost and project's quality. These 3 factors, at least should be as planned, means that on time, on budget and on quality, or better than it has agreed. That's why a regular project progress update has become a very important factor because it can be used by management to control the project, as well as an alert mechanism or early warning sign whether or not the project is on track or off track. This paper adopts the earned value analysis (EVA) that is used to monitor IT project progress, because EVA is a simple formula whilst able to provide a comprehensive information to support decision making.
\end{abstract}

Keywords: indicator, Performance, IT project, Earned Value Analysis

\begin{abstract}
ABSTRAK
Indikator kinerja keberhasilan suatu projek TI (teknologi Informasi) dapat dinilai dari beberapa faktor seperti waktu penyelesaian projek, biaya yang dikeluarkan dan kualitas dari hasil projek . ketiga faktor tersebut minimal harus sesuai yaitu sesuai dengan waktu, sesuai dengan biaya dan sesuai dengan kualitas, atau lebih baik dari rencana yang sudah disetujui. Oleh karena itu, pelaporan secara berkala mengenai progress projek TI menjadi penting karena merupakan suatu kontrol yang dapat digunakan oleh manajemen sebagai alert mechanism (peringatan dini) apakah projek yang sedang berjalan tersebut on track atau off track. Tulisan ini mengadopsi konsep Earned Value analysis (EVA) yang digunakan untuk memonitor progress projek IT, karena EVA merupakan perhitungan yang sederhana namun mampu untuk memberikan informasi yang cukup untuk mendukung pengambilan keputusan.
\end{abstract}

Kata kunci: Indikator, Kinerja, Project TI, Earned Value Analysis 


\section{PENDAHULUAN}

Manajemen projek Teknologi Informasi (TI) menjadi begitu penting didalam kesuksesan implementasi sebuah solusi teknologi informasi. Pada saat ini, seorang manajer projek dituntut untuk memiliki berbagai kemampuan dan pengetahuan hard skill maupun soft skill yang dapat mendukung pencapaian tujuan-tujuan projek yang sedang ditanganinya.

Salah satu kemampuan yang utama itu adalah bagaimana seorang manajer projek mampu untuk me-manage ekspektasi dari stakeholder proyek dengan memberikan informasi yang tepat dan bermanfaat bagi mereka, misalnya seperti sponsor projek atau manajemen senior mendapatkan informasi yang tepat dan bermanfaat mengenai projeknya setiap saat sehingga akan meningkatkan kepuasan dan kepercayaan mereka bahwa projeknya dapat diselesaikan sesuai dengan yang direncanakan dan berkualitas tinggi, yaitu tepat waktu, tepat biaya (on budget), dan sesuai dengan yang diminta (on scope).

Update juga diinformasikan kepada semua pengguna (user) yang terlibat didalam project sehingga mereka memiliki pemahaman yang baik mengenai projek yang sedang melibatkan bagiannya, seperti apa keuntungan projek itu untuk mereka, apa saja yang akan berubah, apa saja proses-proses baru yang akan mereka pelajari dan sebagainya, juga anggota projek mendapatkan informasi yang tepat dan bermanfaat sehingga dapat meningkatkan semangat team, meningkatkan produktifitas, meningkatkan efisiensi yang pada akhirnya dapat mencapati kesuksesan dari projek tersebut.

Pelaporan project progress secara regular merupakan salah satu cara didalam memberikan informasi yang tepat dan bermanfaat bagi stakeholder proyek. Namun demikian tidaklah mudah untuk membuat laporan project progress, sebagian dikarenakan keunikan dari proyek TI itu sendiri, misalnya seperti output dan benefit dari proyek TI kebanyakan adalah tidak berwujud sehingga mungkin dapat diasumsikan pelaporannya akan lebih subjektif tergantung dari persepsi dan metode yang digunakan. Selain itu proyek TI juga pada saat ini semakin kompleks, misalnya seperti terdiri dari puluhan bahkan ratusan tasks (work breakdown structure), lokasi virtual dari setiap team membernya sampai kepada teknologi platform yang digunakan bervariasi. Hal seperti di atas akan lebih menyulitkan seorang project manajer untuk meng-update project progress-nya.

Pelaporan project progress yang sering digunakan oleh seorang project manager biasanya adalah dengan membandingkan project plan dengan deliverable yang sudah ditentukan sebelumnya, namun demikian beberapa orang menilai bahwa pelaporan project progress dengan hanya melihat kepada project plan vs deliverable kurang memberikan informasi yang lengkap, karena didalamnya tidak memiliki informasi mengenai status dari cost, schedule dan scope analysis yang sangat penting didalam membantu pengambilan keputusan ditingkat strategic maupun operational , misalnya seperti berapa persen efisiensi maupun defisiensi yang sudah terjadi , berapa besar hasil yang sudah didapat dibandingkan dengan pengeluaran yang didapat, apakah projek dapat dikatakan on schedule, on budget dan onscope, apa yang harus dilakukan untuk meningkatkan situasi ini, dan sebagainya.

Earned Value merupakan salah satu metode yang dapat digunakan untuk menjawab pertanyaan diatas. Earned value adaalah tools yang dapet digunakan untuk mengukur kinerja dari IT Project dengan cara menganalisa secara comprehensive ketiga faktor utama sebuah project yaitu cost, schedule dan scope. Selanjutnya, tulisan ini akan membahas penggunaan Earned value analysis didalam mengukur kinerja projek-projek teknologi informasi. 


\section{METODE}

Analisa pengukuran project progress dengan menggunakan Earned Value Analysis bertujuan untuk mengukur hasil kinerja aktual dari sebuah pekerjaan dengan biaya dan jadual berdasarkan rencana awal yang sudah ditetapkan. Pengukuran dengan metode ini digunakan untuk melengkapi pelaporan yang biasanya hanya mengukur kinerja project yang terpisah antara pengukuran dari sisi waktu pekerjaan, hasil pekerjaan dan biaya yang sudah dikeluarkan. Dengan earned value analysis seorang project manajer akan mampu melaporkan project progressnya dengan memperhatikan faktor manajemen resiko.

Analisis earned value juga dapat digunakan untuk menganalisa estimasi biaya yang perlu dikeluarkan didalam menyelesaikan projek tersebut, memberikan informasi perbedaan jadual dan biaya antara perencanaan dan actual selama projek sedang berjalan, mengidentifikasi masalah-masalah di awal, memberikan rekomendasi untuk menyelesaikan masalah, sampai kepada perencanaan ulang manajemen projek. Dengan mengintegrasikan ketiga pengukuran yaitu hasil kerja, biaya dan waktu, maka evaluasi dan perbandingan progress antara projek juga dapat dilakukan dengan mudah.

Konsep formula earned value sudah digunakan semenjak awal tahun 60-an, lebih dikenal dengan nama Cost/Schedule Control Systems Criteria (C/SCSC), dan biasanya sudah banyak digunakan tanpa disadari oleh seorang projek manajer, biasanya mereka akan membandingkan antara biaya yang direncakana dengan pembelanjaan yang sudah dikeluarkan dan dibandingkan dengan hasil kerja yg sudah diselesaikan. Pada masa ini, perhitungan Earned Value semakin dimatangkan dengan memperhatikan details pada tasks , misalnya seperti tasks yang di kategorikan kepada beberapa group atau cluster (compartmentalize), sehingga lebih terorganize dan mudah untuk di ukur.

Variabel indicator utama dari earned value adalah: (1) Planned Value (PV), rencana biaya sebuah task pada suatu periode waktu; (2) Actual Cost (AC), biaya task yang terjadi pada suatu periode waktu; (3) Earned Value (EV), biaya yang sudah di anggarkan untuk sebuah pekerjaan yang sudah diselesaikan; (4) Budget at Completion (BAC), akumulasi biaya estimasi yang sudah disetujui dari seluruh aktivitas (task) proyek; (5) Estimate at Completion (EAC), akumulasi biaya yang terjadi dijumlahkan dengan estimasi biaya yang akan terjadi; (6) Variances, perbedaan antara apa yang sudah diselesaikan dan perencanaan. Fomula Earned Value dapat dituliskan sebagai: Cost Variance $(\mathrm{CV})=$ EV - AC; Schedule Variance (SV) = EV - PV; Cost performance Index (CPI) = EV/AC; Schedule performance Index $(\mathrm{SPI})=\mathrm{EV} / \mathrm{PV}$.

Analisa Earned Value untuk schedule dapat dilihat dari nilai / value yang dihasilkan dari perhitungan SPI , yaitu jika SPI = 1 maka waktu projek dapat dikatakan sesuai dengan perencanaan , jika SPI $<1$ maka waktu projek dapat dikatakan tidak sesuai dengan perencanaan (terlambat), dan jika SPI $>1$ maka project dapat dikatakan lebih baik dari perencanaan. Sedangkan analisa untuk biaya dapat dilihat dari nilai/value yang dihasilkan dari perhitungan CPI sebagai jika CPI $=1$ maka biaya projek dapat dikatakan sesuai dengan anggaran , jika CPI $<1$ maka biaya projek dapat dikatakan tidak sesuai dengan anggaran (melebihi anggaran), sedangkan jika CPI $>1$ maka biaya projek dapat dikatan lebih baik dari anggaran (efisien).

\section{HASIL DAN PEMBAHASAN}

Keefektifan penggunaan pengukuran earned value analysis didukung oleh faktor-faktor seperti: alokasi penganggaran dengan baik, perencanaan proyek dengan baik, kemampuan untuk membreakdown aktivitas proyek (task) sampai kepada level detil, pengawasan dan pencatatan terhadap 
biaya yang sudah terjadi (misalnya berapa biaya yang sudah dikeluarkan untuk suatu kegiatan/task), serta pengawasan dan pencatatan terhadap status task yang sudah di rencanakan (misalnya persentase selesai). Untuk menjelaskan penggunaan earned value analysis, penulis menggunakan contoh suatu perencanaan projek IT yang sederhana seperti yang digambarkan pada Tabel 1.

Tabel 1 Perencanaan Projek Sistem Sumber Daya Manusia

\begin{tabular}{|c|c|c|c|c|c|}
\hline Aktifitas Projek & Task & $\begin{array}{l}\text { Tanggal } \\
\text { Mulai }\end{array}$ & $\begin{array}{l}\text { Tanggal } \\
\text { Selesai }\end{array}$ & Hari & Estimasi Biaya \\
\hline \multirow[b]{3}{*}{ 1. Tahap Perencanaan } & Studi kelayakan & 1-Jul-10 & 5-Jul-10 & 4 & $3,000,000.00$ \\
\hline & Perencanaan Projek & 6-Jul-10 & 8-Jul-10 & 2 & $2,000,000.00$ \\
\hline & Kick - Off Meeting & 9-Jul-10 & 10-Jul-10 & 1 & $2,000,000.00$ \\
\hline \multirow[b]{5}{*}{ 2. Tahap Analisis } & Mengumpulkan kebutuhan sistem & 12-Jul-10 & 16-Jul-10 & 4 & $10,000,000.00$ \\
\hline & Menganalisa proses bisnis & 19-Jul-10 & 23-Jul-10 & 4 & $4,000,000.00$ \\
\hline & Menganalisa solusi teknologi yang akan digunakan & 26-Jul-10 & $30-J u l-10$ & 4 & $3,000,000.00$ \\
\hline & Menganalisa kebutuhan infrastruktur & 26-Jul-10 & 30-Jul-10 & 4 & $3,000,000.00$ \\
\hline & Menganalisa lebih detail perencanaan projek & 2-Aug-10 & 3-Aug-10 & 1 & $2,000,000.00$ \\
\hline \multirow[b]{8}{*}{ 3. Tahap Rancangan } & $\begin{array}{l}\text { Memverifikasi kebutuhan sistem apakai sesuai } \\
\text { dengan solusi yang direkomendasikan }\end{array}$ & 3-Aug-10 & 5-Aug-10 & 2 & $5,000,000.00$ \\
\hline & Mengidentifikasi kebutuhan tambahan & 6-Aug-10 & 7-Aug-10 & 1 & $2,000,000.00$ \\
\hline & $\begin{array}{l}\text { Merancang kebutukan infrastruktur (hardware, } \\
\text { software, network, database design, user interface, } \\
\text { security, dan sebagainya) }\end{array}$ & 9-Aug-10 & 10-Aug-10 & 1 & $5,000,000.00$ \\
\hline & $\begin{array}{l}\text { Merancang kebutuhan aplikasi (DFD, ERD, flowchart } \\
\text { proses, report, pseudocode, screen design, dan } \\
\text { sebagainya) }\end{array}$ & 11-Aug-10 & 18-Aug-10 & 7 & $10,000,000.00$ \\
\hline & Merancang proses bisnis yang baru & 11-Aug-10 & $18-$ Aug-10 & 7 & $5,000,000.00$ \\
\hline & Merancang solusi alternatif & 19-Aug-10 & 20-Aug-10 & 1 & $5,000,000.00$ \\
\hline & Merancang solusi yang direkomendasikan & 23-Aug-10 & $24-$ Aug-10 & 1 & $2,000,000.00$ \\
\hline & Membuat Prototype sistem & 25-Aug-10 & 31-Aug-10 & 6 & $15,000,000.00$ \\
\hline \multirow{4}{*}{$\begin{array}{l}\text { 4. Tahap Pembuatan } \\
\text { dan Penerapan }\end{array}$} & Menginstall infrastruktur & 15-Aug-10 & 22-Aug-10 & 7 & $50,000,000.00$ \\
\hline & Membangun sistem & 1-Sep-10 & 30-Sep-10 & 29 & $150,000,000.00$ \\
\hline & $\begin{array}{l}\text { Testing (sistem test, user test, infrastruktur test, } \\
\text { dan sebagainya) }\end{array}$ & 1-Oct-10 & $8-O c t-10$ & 7 & $10,000,000.00$ \\
\hline & Mengimplmentasi aplikasi & $10-$ Oct-10 & 11-Oct-10 & 1 & $10,000,000.00$ \\
\hline 5. Tahap Penggunaan & Mengevaluasi aplikasi & 11-Oct-10 & 11-Nov-10 & 31 & $2,000,000.00$ \\
\hline \multicolumn{4}{|c|}{ Total Estimasi Waktu (Hari) dan Biaya (Rupiah) } & 125 & $300,000,000.00$ \\
\hline
\end{tabular}

Tabel 1 membagi aktivitas proyek menjadi lima bagian besar, dan setiap bagian memiliki beberapa task. Jika pada tanggal 23 Juli 2010, status task dan biaya adalah seperti pada Tabel 2 (Status projek task pada tanggal 23 Juli 2010). 
Tabel 2 Status projek task pada tanggal 23 Juli 2010

\begin{tabular}{|c|c|c|c|c|c|c|c|}
\hline Aktifitas Projek & Task & $\begin{array}{l}\text { Tanggal } \\
\text { Mulai }\end{array}$ & $\begin{array}{l}\text { Tanggal } \\
\text { Selesai }\end{array}$ & Hari & Estimasi Biaya & $\begin{array}{c}\text { Status task } \\
\text { pada tanggal } \\
23 \text { Juli } 2010\end{array}$ & Biaya Aktual \\
\hline \multirow[b]{3}{*}{ 1. Tahap Perencanaan } & Studi kelayakan & 1-Jul-10 & 5-Jul-10 & 4 & $3,000,000.00$ & $100 \%$ & $2,000,000.00$ \\
\hline & Perencanaan Projek & 6-Jul-10 & 8-Jul-10 & 2 & $2,000,000.00$ & $100 \%$ & $2,500,000.00$ \\
\hline & Kick - Off Meeting & 9-Jul-10 & 9-Jul-10 & 0 & $2,000,000.00$ & $100 \%$ & $1,000,000.00$ \\
\hline \multirow[b]{5}{*}{ 2. Tahap Analisis } & Mengumpulkan kebutuhan sistem & 12-Jul-10 & $16-J u l-10$ & 4 & $10,000,000.00$ & $100 \%$ & $9,000,000.00$ \\
\hline & Menganalisa proses bisnis & 19-Jul-10 & 23-Jul-10 & 4 & $4,000,000.00$ & $0 \%$ & 0 \\
\hline & $\begin{array}{l}\text { Menganalisa solusi teknologi yang } \\
\text { akan digunakan }\end{array}$ & 26-Jul-10 & 30-Jul-10 & 4 & $3,000,000.00$ & $0 \%$ & 0 \\
\hline & Menganalisa kebutuhan infrastruktur & 26-Jul-10 & 30-Jul-10 & 4 & $3,000,000.00$ & $0 \%$ & 0 \\
\hline & $\begin{array}{l}\text { Menganalisa lebih detail } \\
\text { perencanaan projek }\end{array}$ & 2-Aug-10 & 3-Aug-10 & 1 & $2,000,000.00$ & $0 \%$ & 0 \\
\hline \multirow[b]{8}{*}{ 3. Tahap Rancangan } & $\begin{array}{l}\text { Memverifikasi kebutuhan sistem } \\
\text { apakai sesuai dengan solusi yang } \\
\text { direkomendasikan }\end{array}$ & 3-Aug-10 & 5-Aug-10 & 2 & $5,000,000.00$ & $0 \%$ & 0 \\
\hline & \begin{tabular}{|l|}
$\begin{array}{l}\text { Mengidentifikasi kebutuhan } \\
\text { tambahan }\end{array}$ \\
\end{tabular} & 6-Aug-10 & 6-Aug-10 & 0 & $2,000,000.00$ & $0 \%$ & 0 \\
\hline & $\begin{array}{l}\text { Merancang kebutukan infrastruktur } \\
\text { (hardware, software, network, } \\
\text { database design, user interface, } \\
\text { security, dan sebagainya) }\end{array}$ & 9-Aug-10 & 10-Aug-10 & 1 & $5,000,000.00$ & $0 \%$ & 0 \\
\hline & \begin{tabular}{|l|} 
Merancang kebutuhan aplikasi \\
(DFD, ERD, flowchart proses, \\
report, pseudocode, screen design, \\
dan sebagainya) \\
\end{tabular} & 11-Aug-10 & 18-Aug-10 & 7 & $10,000,000.00$ & $0 \%$ & 0 \\
\hline & Merancang proses bisnis yang baru & 11-Aug-10 & 18-Aug-10 & 7 & $5,000,000.00$ & $0 \%$ & 0 \\
\hline & \begin{tabular}{|l|} 
Merancang solusi alternatif \\
\end{tabular} & 19-Aug-10 & $20-$ Aug-10 & 1 & $5,000,000.00$ & $0 \%$ & 0 \\
\hline & \begin{tabular}{|l}
$\begin{array}{l}\text { Merancang solusi yang } \\
\text { direkomendasikan }\end{array}$ \\
\end{tabular} & 23-Aug-10 & 24-Aug-10 & 1 & $2,000,000.00$ & $0 \%$ & 0 \\
\hline & Membuat Prototype sistem & $25-$ Aug-10 & 31-Aug-10 & 6 & $15,000,000.00$ & $0 \%$ & 0 \\
\hline \multirow{4}{*}{$\begin{array}{l}\text { 4. Tahap Pembuatan } \\
\text { dan Penerapan }\end{array}$} & Menginstall infrastruktur & 15-Aug-10 & 22-Aug-10 & 7 & $50,000,000.00$ & $0 \%$ & 0 \\
\hline & Membangun sistem & 1-Sep-10 & 30-Sep-10 & 29 & $150,000,000.00$ & $0 \%$ & 0 \\
\hline & \begin{tabular}{|l|} 
Testing (sistem test, user test, \\
infrastruktur test, dan sebagainya)
\end{tabular} & 1-Oct-10 & 8-Oct-10 & 7 & $10,000,000.00$ & $0 \%$ & 0 \\
\hline & Mengimplmentasi aplikasi & 10-Oct-10 & 10-Oct-10 & 0 & $10,000,000.00$ & $0 \%$ & 0 \\
\hline 5. Tahap Penggunaan & Mengevaluasi aplikasi & 11-Oct-10 & 11-Nov-10 & 31 & $2,000,000.00$ & $0 \%$ & 0 \\
\hline \multicolumn{4}{|c|}{ Total Estimasi Waktu (Hari) dan Biaya (Rupiah) } & 122 & $300,000,000.00$ & & \\
\hline
\end{tabular}

Maka analisis eaned value dapat dihitung dengan menggunakan formula sebagai berikut:

$$
\begin{aligned}
& \text { Planned Value (PV) } \quad: 3 \text { juta }+2 \text { juta }+2 \text { juta }+10 \text { juta }+4 \text { juta }=21 \text { Juta } \\
& \text { Actual Cost (AC) : : } 2 \text { juta }+2.5 \text { juta }+1 \text { juta }+9 \text { Juta } \quad=14.5 \text { Juta } \\
& \text { Earned Value (EV) } \quad: 3 \text { juta }+2 \text { juta }+2 \text { juta }+10 \text { juta } \quad=17 \text { Juta } \\
& \text { Cost Variance (CV) } \quad=\mathrm{EV}-\mathrm{AC} \\
& =17 \text { juta }-14.5 \text { Juta } \\
& =2,5 \text { juta } \\
& \text { Schedule Variance }(\mathrm{SV}) \quad=\mathrm{EV}-\mathrm{PV} \\
& =17 \text { juta }-21 \text { Juta } \\
& =-4 \text { Juta } \\
& \text { Cost performance Index (CPI) } \quad=\text { EV/AC } \\
& =17 \text { juta } / 14.5 \text { juta } \\
& =1.17
\end{aligned}
$$

Schedule performance Index $(\mathrm{SPI})=\mathrm{EV} / \mathrm{PV}$

$$
\begin{aligned}
& =17 \text { juta } / 21 \text { juta } \\
& =0.80
\end{aligned}
$$


Dari hasil perhitungan diatas, dapat disimpulkan bahwa biaya projek (project cost) lebih baik dari anggaran (karena CPI $>1$ ) dengan nilai cost variance sebesar 2.5 juta rupiah, sedangkan waktu projek (project schedule) tidak sesuai dengan perencanaan, dengan nilai schedule variance sebesar 4 juta rupiah. Selanjutnya project manager perlu menambahkan inisiatif-inisiatif (action items) apa saja yang akan diambil untuk memperbaiki kinerja projeknya, misalnya seperti mengalokasikan sumber daya tambahan, mereview kembali prioritas task - task projek, melihat factor-faktor penghambat lainnya seperti komitmen dari stakeholder, me-review kembali ruang lingkup proyek dan sebagainya.

\section{SIMPULAN}

Penggunaan earned value analysis didalam mengukur kinerja projek - projek TI akan memberikan gambaran yang lebih lengkap terhadap performa projek yang sedang berjalan, hal ini sangat bermanfaat sehingga projek manager dan stakeholder dapat mereview keseluruhan performa projek dan melakukan tindakan - tindakan yang tepat didalam meningkatkan kinerja projeknya tersebut.

Seperti yang telah disebutkan diatas bahwa keefektifitasan penggunaan metode ini di pengaruhi oleh beberapa faktor seperti perencanaan dan penganggaran yang tepat, kemampuan untuk membreakdown kegiatan kegiatan (tasks) proyek dengan detil, pengawasan dan pencatatan mengenai status task dari projek. Pada tulisan selanjutnya disarankan untuk membahas dan mendalami prosesproses tersebut.

\section{DAFTAR PUSTAKA}

Duncan, W. R. (1996). A guide To the Project Management Body of Knowledge: Automated Graphic Systems. Maryland, USA: White Plains.

Valle, J. A., \& Soares, C. A. P. (2004) The Use of Earned Value Analysis (EVA) in the Cost Management of Construction Projects, from http://www.icoste.org/ICMJ\%20Papers/Valle\%20-\%20EVA.pdf

Sumara, J., \& Goodpasture, J. (1997). Earned Value-The Next Generation-A Practical Application for Commercial Projects. Project Management Institute 28th Annual Seminars \& Symposium. Chicago, Illinois. 